west reaches the waters of Jones Sound in their northern extensions.

The importance of the northern work is not confined, as many think, to the mere planting of the American flag a few miles nearer the northern axis of the globe than has floated the standard of any other nation. Lockwood's journey has gone very far towards settling the much-vexed geographical question, the configuration and northern extension of Greenland. The farthest point seen is scarcely three hundred miles from the land of Lambert, sighted on the east coast in 1670 , and less than four hundred and twenty-five from the most northern point of Koldeway and Payer. Of the fortyseven degrees of longitude between Fort Conger and Cape Bismarck, but twenty remain unknown. I venture the opinion that future voyages will confirm the indications growing out of our discoveries, that Arthur Land is separated from Grinnell Land by a fiord or channel connecting the western polar ocean with Hayes Sound. I also think that the northern coast-lines of the Parry Archipelago will be found trending gradually in a northeasterly direction, and terminating in Arthur Land. On these points, as well as on the remarkably fertile belt of iceless country found by me in the interior of Grinnell Land, such as Nordenskiöld hoped to find in Greenland, I trust soon to dwell at length in a forthcoming narrative.

$$
\text { A. W. Greely, Lieut. U. S. army. }
$$

\section{THE CONFIGURATION OF GRINNELL LAND AND ELLESMERE LAND.}

The discoveries of the Greely expedition on the west shore of Grinnell Land are most valuable and important, as there was a vast field for conjecture concerning the configuration of the coast-line of this large island. The exploration of the north shore by Lieut. Aldrich of Nares' expedition proved the improbability of any great extension to the west. The discovery of the west shore at so short a distance as Lieut. Lockwood found it, was, however, quite unexpected. From the description of Hayes Sound, obtained by Dr. Bessels from the Smith-Sound natives, and from information and drawings I received last summer during my stay on Davis Strait from natives who had crossed Lancaster and Jones Sound, and lived on Eilesmere Land, it is possible to learn something more about this long and unexplored coast.

The most exact description received was from an Eskimo woman whom I met at Cape Kater. She was born at Igluling in Fury and Hecla Strait, had lived some time in Repulse Bay, returned to Igluling, and afterwards crossed the land to Admiralty Inlet, which the natives call ' 'Tudnunirossirn.' There she lived for a number of years; and about fifteen years ago she started with a party to North Devon, which the Eskimo call 'Tudjan.' There is little intercourse between Baffin Land and North Devon, Lancaster Sound being seldom covered by a solid ice-floe. The north shore of Baffin Land ('Weevang' of the natives) is generally washed by water during the whole winter.

Crossing the sound on sledges, these Eskimo passed a very small island, most probably the rock seen by Capt. Adams in 1871, and in two or three days reached the opposite shore. They did not follow the shores of North Devon, but crossed the ice-covered island on sledges. In four days they reached the north shore, whence a long and narrow peninsula, Nedlung, stretches to Ellesmere Land (their ' Oomingmam nuna,' i.e., musk-ox land). 'Through the narrow passage dividing Tudjan from Nedlung runs a very strong tidal current, which keeps open a waterhole throughout the winter. All around this place the ice wastes quickly in the spring, and forms a large basin of water abounding with seals. Only that part of the peninsula which lies nearest to North Devon is high and steep, and forms a bold face : farther north it is very low. The length of Nedlung may be about forty miles; its width, three or four miles. West of it there are numerous small islands, called 'Kikkertakdjuin :' to the east there are no islands.

Having reached Oomingmam nuna, the Eskimo fell in with a small tribe residing on this shore. Here they lived for some time, as an abundance of seals was found during the whole year. Farther north-west there is a large fiord, called 'Kangirtuksiak,' off which an island is found, Kikkertakadlinang. The Eskimo did not go to the land on the other side of the fiord, as polar bears are said to be very numerous and large there.

I obtained this information by most careful and minute investigation on every point. I also heard some less detailed descriptions of the journey to Oomingmam nuna by natives of Ponds Bay, who had not been there themselves, but had heard about it from their ancestors; and I may here state that all their traditions and descriptions which I had a chance to verify proved accurate and reliable.

There can be no doubt about the identity of Tudjan and North Devon, as they say that 
the land can be seen from Weevang (the north shore of Baffin Land) ; and many natives have lived there, and have been seen by whalers, and by the expeditions sent in search of Sir John Franklin.

The report on the state of the ice in Jones Sound is very important for the identification of this place. As there is a narrow neck of

covered many small islands. The open water, the narrow passage between North Kent and North Devon, and the many small islands to the north, closely resemble the description given me by the Eskimo woman. It would be very interesting to find that Jones Sound is closed there by a narrow neck of land. The heavy ice Inglefield met with in Jones Sound, in 1852, may have drifted into the sound as easily from Smith Sound as from a sea west of Ellesmere Land.

The last reason leading me to think that Ellesmere Land and Oomingmam nuna are the same, is that the same name is applied to Ellesmere Land by the SmithSound natives. In Etah, Bessels met a man who came from Cape Searle, on Davis Strait. He had lived for some time among the Ellesmere-Land natives, and referred to that country as Oomingmam nuna. In the whole of Baffin Land the natives know Oomingmam nuna, and always point it out as beyond Tudnunirn (Ponds Bay) and Tudjan. For these reasons there can scarcely be any doubt that the description I obtained really refers to Jones Sound and the west shore of Ellesmere Land.

The Eskimo of Etah assert that Hayes Sound is a passage leading into the western ocean, and dividing the land west of the Smith-Sound seas into two islands,-Ellesmere Land and Grinnell Land; and there is no reason to doubt their statements. The English expedition under Nares supposed the sound not to be open to tidal currents ; Greely's explorations, however, ex-

land connecting Cornwallis and Bathurst Islands, I was rather inclined to judge this to be the place where my Eskimo had been. However, her memory would barely have failed her in recollecting the passage over the ice of Wellington Channel ; and besides, the description of the land, Oomingmam nuna, does not agree with Bathurst Island. In Jones Sound, Belcher found open water in May, 1853, at a time of the year when the ice in narrow channels can only be wasted by strong currents. We know nothing about the part of the sound north-east of North-Kent Island, north of which Belcher distend it much farther to the west, and are rather in favor of the theory that the sound really forms a passage. The accompanying map presents my views of the probable configuration of the land in this region. Dr. Franz Boas.

\section{PALENQUE VISITED BY CORTEZ.}

A Memorr by Mr. Teobert Maler upon the state of Chiapas (Mexico), published in the July and August numbers, 1884, of the Revue d'ethnographie, contains some items of more 